\title{
Two-step Synthesis of $\mathrm{LiVP}_{2} \mathrm{O}_{7} / \mathrm{C}$ for Use as Cathode Material in Lithium-Ion Batteries
}

\author{
Huayi Yu ${ }^{1}$, Zhi Su ${ }^{1,2, *}$, Hualing Tian ${ }^{1,2}$ \\ ${ }^{1}$ College of Chemistry and Chemical Engineering, Xinjiang Normal University, Urumqi, 830054, \\ Xinjiang, China \\ ${ }^{2}$ Engineering Research Center Of Electrochemical Technology and Application, Xinjiang Normal \\ University, Urumqi, 830054, Xinjiang, China \\ *E-mail: suzhixj@sina.com
}

doi: $10.20964 / 2018.05 .45$

Received: 11 January 2018 / Accepted: 7 March 2018 / Published: 10 April 2018

$\mathrm{LiVP}_{2} \mathrm{O}_{7} / \mathrm{C}$ was synthesized by a novel two-step method, which involves combining the sol-gel method and the high-temperature solid phase method. $\mathrm{VP}_{2} \mathrm{O}_{7}, \mathrm{VOPO}_{4}$, and $\mathrm{LiVOPO}_{4}$ were used as the precursors for producing the $\mathrm{LiVP}_{2} \mathrm{O}_{7} / \mathrm{C}$ composite. The electrochemical performances of the three samples synthesized using the different precursors were compared. It was found that $\mathrm{LiVP}_{2} \mathrm{O}_{7} / \mathrm{C}$ prepared using $\mathrm{VP}_{2} \mathrm{O}_{7}$ as the precursor showed the best electrochemical performance. The initial discharge capacity of this sample was $100.2 \mathrm{mAh} \cdot \mathrm{g}^{-1}$, while its discharge capacity was $90.8 \mathrm{mAh} \cdot \mathrm{g}^{-1}$ after 50 cycles. Moreover, this $\mathrm{LiVP}_{2} \mathrm{O}_{7}$ sample exhibited a high voltage platform of approximately 4.2 $\mathrm{V} / 4.3 \mathrm{~V}$.

Keywords: $\mathrm{LiVP}_{2} \mathrm{O}_{7} / \mathrm{C}$; cathode materials; two-step synthesis method

\section{FULL TEXT}

(C) 2018 The Authors. Published by ESG (www.electrochemsci.org). This article is an open access article distributed under the terms and conditions of the Creative Commons Attribution license (http://creativecommons.org/licenses/by/4.0/). 